\title{
Marcadores cruzados: etnicidade, homossexualidade e religião*
}

\author{
Martinho Tota Filho Rocha de Araújo**
}

\section{Resumo}

O escopo deste artigo consiste em investigar - a partir de um estudo de caso desenvolvido no litoral norte do estado da Paraíba - as possíveis articulações entre etnicidade, homossexualidade e religião, tomando-os como campos de experiência coletivos $e$ individuais que, embora relativamente autônomos, podem emergir em variadas modalidades de conjugação, dependendo dos contextos socioculturais $e$ interativos, dos atores envolvidos e da natureza das relações sociais.

Palavras-chave: Etnicidade, Homossexualidade, Religião, Interseccionalidade.

* Recebido para publicação em 31 de maio de 2013, aceito em 6 de junho de 2016.

** Professor do Departamento de Ciências Sociais, Universidade Federal do Ceará (UFC), Fortaleza, CE, Brasil. martinho.tota@gmail.com 
Markers Crusaders:

Ethnicity, Homosexuality And Religion

\begin{abstract}
The scope of this paper is to investigate - from a case study conducted on the northern coast of Paraíba state - the possible links between ethnicity, homosexuality and religion, taking these fields as individual and collective experience that, while relatively autonomous, can emerge in various forms of combination, depending on the sociocultural and interactive context, the actors involved and the nature of social relations.
\end{abstract}

Keywords: Ethnicity, Homosexuality, Religion, Intersectionality. 


\section{Introdução}

A pesquisa que desenvolvi nos anos de 2009 e 2010 na Baía da Traição e em Marcação, dois municípios localizados na microrregião do litoral norte da Paraíba, tinha como um de seus objetivos verificar as possíveis articulações entre etnicidade $e$ homossexualidade. O estudo empreendido concentrou-se no núcleo urbano da Baía da Traição e em cinco aldeias da Terra Indígena Potiguara. Apenas uma aldeia, situada em Marcação, foi contemplada. ${ }^{1}$ No decorrer de meu percurso investigativo, estabeleci contato com dezenas de indivíduos que se autodefiniam como homossexuais ou travestis. Dentre eles, 26 me concederam entrevistas gravadas. Nos demais casos, contei com diálogos $e$ encontros informais, os quais igualmente me forneceram informações de grande relevância. Quanto às suas identidades étnicas autoatribuídas, meus interlocutores encontravam-se distribuídos nas categorias: "índio"/"índio puro"/"índio legítimo", "descendente"/"misturado"/"mestiço"/"aculturado" e "branco"/"não índio".

Em meu trabalho de campo, fui guiado por questionamentos do tipo: em que medida os marcadores étnico e sociossexual interferiam, influenciavam ou se apoiavam um no outro? Sob que aspectos o "ser índio" poderia incidir numa manifestação particular da sexualidade ou do erotismo? Ou, por outro lado, como o desejo se moldaria aos indivíduos na condição de membros de uma coletividade etnicamente diferenciada? $\mathrm{E}$

1 Segundo dados do Instituto Brasileiro de Geografia e Estatística (IBGE), referentes ao ano de 2010, Baía da Traição contava com uma população de 8.012 habitantes, dos quais 5.687 eram definidos como indígenas. No entorno desse município encontram-se 14 aldeias, que constituem a Terra Indígena Potiguara, ocupando uma área de 21.238 hectares. Quanto a Marcação, município que fica a 66 quilômetros de João Pessoa, sua população era de 7.609 habitantes, dos quais 5.895 eram classificados como indígenas (IBGE:2010). Esse município abrigava a Terra Indígena Jacaré de São Domingos (também da etnia Potiguara), composta por outras 14 aldeias, as quais, juntas, ocupavam uma área de 5.032 hectares. 
qual o grau de inserção e/ou exclusão de indivíduos homossexuais nas redes sociais de sua coletividade?

Procuro neste artigo analisar tais questóes. Para tanto, julgo producente organizar o texto em três tópicos. No primeiro, recorro a uma breve revisão bibliográfica de alguns trabalhos que têm a etnicidade como temática $e$, em seguida, procedo à descrição das formas pelas quais meus interlocutores definiram suas identidades étnicas. No segundo, apresento os aspectos acionados pelos entrevistados em suas interpretações da homossexualidade, procurando escrutar suas possíveis articulações com a etnicidade. Finalmente, no terceiro tópico, apresento um marcador social que acabou se impondo pelos discursos das pessoas com quem tive contato e que me pareceu desempenhar um papel preponderante quando conjugado à homossexualidade, muitas vezes ofuscando o fator étnico. Refiro-me à religião, tanto como crença - com a qual os indivíduos são socializados e que engendra um determinado padrão de moralidade - quanto como instituição à qual foram atribuídas a disseminação e a cristalização do preconceito e da homofobia.

\section{Primeiro marcador: etnicidade}

Historicamente, percebemos que o termo "étnico" está alicerçado numa noção segundo a qual um "grupo étnico" seria formado por um agregado de indivíduos mais ou menos inseridos ou em contato com um coletivo maior, geralmente cultural, social, política e economicamente hegemônico. No âmbito das ciências sociais, Weber (1991), ainda que não tenha sido o primeiro a formular uma definição acerca dos grupos étnicos, consta como uma referência ubíqua nos trabalhos dedicados ao tema. As características apontadas por esse autor, definidoras desses grupos, continuam a ser evocadas - mesmo que apresentando ênfases variadas - na literatura sobre tal fenômeno. Dentre elas encontram-se as fronteiras instauradas entre coletivos étnicos a ponto de muitos deles isolarem-se monopolisticamente. Os processos de fronteirização, responsáveis por tal isolamento, 
encontrariam sua fonte no sentimento coletiva e subjetivamente compartilhado pelos indivíduos de que teriam em comum uma origem, hábitos, costumes, honra e dignidade capazes de uni-los e diferenciá-los de outros coletivos. De acordo com Weber (1991), no entanto, mais que uma comunidade, um grupo étnico propiciaria a instauração de relações comunitárias, sobretudo de natureza política, pois seria dentro desse campo de ação (instituído por meio de um conjunto de práticas racionais) que se engendraria a crença numa possível comunhão étnica $e$, por conseguinte, uma comunidade de intercâmbio social.

Apesar da contribuição dada por Weber (1991), suas ideias não se difundiram muito nos primeiros anos que se seguiram ao seu Economia e Sociedade. De acordo com Poutignat e StreiffFenart (1998), isso só viria a ocorrer na década de 1940, quando a etnicidade, instrumentalizada em referência a grupos não angloamericanos, passou a ser vista como princípio de divisão da vida social. $^{2}$ A despeito das divergências flagrantes nas abordagens apresentadas por inúmeros autores quanto ao fenômeno étnico, algo os aproxima, ainda que superficialmente: trata-se da dicotomia estabelecida entre grupos étnicos e a sociedade envolvente, ou seja, dos processos de fronteirização entre uns e outros. O constructo teórico empreendido por Bourdieu (1989) na formulação do que ele entende por campo social, ainda que não diretamente referido à questão étnica, pode ser transposto como leitura viável dessa problemática. Para esse autor, uma dada etnia poderia ser caracterizada a partir de fatores como: a) as posições

2 De acordo com Stolcke (1993:23-25), o termo étnico começou a ser empregado - ou ao menos foi mais amplamente difundido - no período PósSegunda Guerra, numa crítica à ideologia racista que imperou no Terceiro Reich nazista e culminou no Holocausto. A intenção, afirma a autora, era enfatizar que os grupos humanos, antes de "seres biológicos", são entes culturais e históricos. A distinção entre raça e etnia, por conseguinte, relegou a primeira à instância da natureza, ao passo que a segunda foi colocada no domínio da cultura. Escapando a essa dicotomia, Stolcke (1993:29-30) acredita que tanto raça quanto etnicidade são artifícios simbólicos usados sob certas circunstâncias sociopolíticas para definir e marcar grupos humanos. 
ocupadas por seus membros; b) a "taxa de dispersão" de tais posições; e c) o "grau de integração social". Nesse sentido, caberia ao estudioso perscrutar

a disputa pelo privilégio de impor uma visão das coisas, [as] lutas pelo monopólio de fazer ver e fazer crer, de dar a conhecer e de fazer reconhecer, de impor a definição legítima das divisões do mundo social e, por este meio, de fazer e de desfazer os grupos (Bourdieu, 1989:113, apud Grünewald, 2004:157-158).

A partir dos anos 1970, o centro das atenções dos antropólogos interessados na temática étnica passou a ser justamente a questão das fronteiras, a qual adquiriu outro patamar heurístico com os trabalhos de Barth (1984, 1998, 2000), que desloca a ênfase até então conferida aos "conteúdos" étnicos rumo aos espaços e contextos intersticiais envolvendo grupos ou sociedades etnicamente diferenciados. Para o autor, tal procedimento analítico se justificaria pelo fato de que as "fronteiras persistem apesar do fluxo de pessoas que as atravessam" (Barth, 1998:188, 194). Em meio a esse processo dinâmico, as distinções de categorias étnicas se inscrevem num quadro de mobilidade, contato e informação $e$, a despeito de sua fluidez e dinamicidade, as diferenças intergrupais, longe de serem apagadas, são criativa e politicamente construídas e performadas. Nesse sentido,

as categorias étnicas fornecem um cadinho organizacional dentro do qual podem ser colocados conteúdos de formas $e$ dimensões várias em diferentes sistemas socioculturais. Tais categorias podem ter grande importância para $\mathrm{o}$ comportamento e permear toda a vida social dos sujeitos, mas também podem ser relevantes apenas para setores limitados de atividade (Barth, 1998:194).

Para Barth (1998), portanto, uma identidade étnica não coincide necessariamente com um modo de vida específico nem 
com um grupo real de pessoas, mas tem a ver com a "natureza circunstancial da escolha de uma identidade étnica em meio a outras escolhas de identificação possíveis" (cf. Poutignat; StreiffFenart, 1998:63-64).

Em obra posterior, Barth (1984:82-87) afirma que, dentro de qualquer cenário caracterizado pelo pluralismo cultural, a etnicidade fornecerá uma estrutura "puramente ilusória para investigar os reais corpos de crenças, valores e práticas distribuídas na população", ainda que no final das contas ela sirva para identificar um conjunto de forças que afetam essa distribuição, pois ela tem significações pautadas tanto na experiência de vida de cada sujeito quanto é afetada por elementos exógenos ao grupo. Uma vez que tradições ou culturas são delimitadas de maneira sutil, é preciso procurar sistemas mais amplos para especificar os contextos e a forma pela qual os materiais culturais são externamente distribuídos, adverte o autor.

Um dos grandes méritos da proposta barthiana foi enxergar no fenômeno étnico seu aspecto eminentemente situacional $e$ dinâmico, o que foi seguido por um numeroso contingente de pesquisadores (ver, entre outros, Nagata, 1974; Ronald Cohen, 1978; Okamura, 1981; Eriksen, 1991). No Brasil, intelectuais do porte de Cardoso de Oliveira $(1976,2006)$ - um dos primeiros a difundir a perspectiva analítica de Barth no país - saudaram o autor entusiasticamente e, desde então, seus postulados vêm inspirando gerações de estudiosos (cf. Barreto Filho, 1993, 2004; Grünewald, 1993; Martins, 1994; Pacheco de Oliveira, 2004; Valle, 1993, entre outros). Segundo Pacheco de Oliveira (1988:58-59), com Barth "se inverte a postura tradicional, de que primeiro as unidades culturais são definidas e internamente organizadas, depois mantêm relações externas umas com as outras". Na verdade, o próprio "contato interétnico" seria a força motriz a partir da qual se estabeleceria a "identidade de um grupo étnico" (ênfases do autor).

A teoria barthiana, contudo, apesar de sua hegemonia, jamais foi um consenso. Keyes (1976), por exemplo, discorda das definições "culturalistas" e situacionais da etnicidade. Às vezes tachado de "primordialista", o fato é que esse autor traz à baila uma 
questão pertinente, qual seja, a ideia de que a descendência comum funciona como fator "primordial" para a definição do étnico. Numa crítica dirigida a Barth, Keyes (1976:203) afirma que, ao priorizar o caráter situacional da etnicidade, o fator étnico acaba sendo uma questão inteiramente arbitrária e sem valor analítico. Tendo isso em mente, Keyes (1976:204-210) enfatiza os "fatos do nascimento" sexo, características biológicas, data e local de nascimento e, sobretudo, linha de descendência - como o fundamento da etnicidade, uma vez que é a partir desses "fatos" que os indivíduos e grupos criam diferenciações e constroem um "senso identitário".

Igualmente inquietado com a proposta barthiana, Aronson (1976) se pergunta: “o que é 'étnico' em relação aos grupos étnicos?". Para ele, se não há nada que divida substancialmente a "classe" étnica da não étnica, deveríamos abandonar o uso do termo. Na verdade, Aronson (1976), como Barth (1998), sustenta que as identidades étnicas são construídas interativamente; que, longe de essenciais, são situacionais. Entretanto, o que move os sujeitos numa arena conflitiva interétnica são os "interesses políticos". Enfatizando o uso "político das 'diferenças", Aronson (1976) propõe que a etnicidade seja vista como "um tipo particular de ideologia", uma ideologia "do e para o dissenso, para a autonomização de valores em uma arena sociopolítica inclusiva". Ao contrário das ideologias de classe - que assumem ou buscam por valores consensuais -

uma ideologia étnica diz que não concordamos com os valores últimos do sistema. Do ponto de vista dos indivíduos, precisamos analisar como diferentes ideologias relativas às suas "identidades básicas, mais gerais", algumas étnicas e outras não, se articulam umas com as outras em situações iguais ou diferentes, de forma que possamos julgar os efeitos de fidelidades conflitantes, clivagens cumulativas e assim por diante (Aronson, 1976:14).

Similarmente, Abner Cohen (1974) admite que, antes de isolada, a etnicidade se constrói relacionalmente dentro de uma arena conflitiva num Estado-Nação "com uma divisão de trabalho 
altamente avançada e intensa luta por recursos como trabalho, salários, moradia e adesão política" (cf. Williams, 1989), estando inserida num campo instaurado por interconexões políticas, econômicas, psicológicas, históricas, simbólicas, comportamentais e organizacionais.

Os autores acima mencionados colocam a existência dos grupos étnicos como problemática e, a despeito das divergências entre eles, as correntes teóricas que representam "apontam para dimensões constitutivas, sem as quais a etnicidade não poderia ser pensada" (Pacheco de Oliveira, 2004:32-33). Quanto aos "índios do Nordeste" brasileiro, o que essa literatura tem a nos dizer? Para Martins (2004:227-228), tudo, uma vez que "a questão indígena [nessa região do país] está fundamentalmente vinculada a um contexto político contemporâneo, ligado a situações de territorialidade e de identificação étnica". De acordo com a autora, a "indianidade tem se dado através da utilização de um etnônimo específico, estabelecendo fronteiras étnicas através de sinais diacríticos". Quanto à territorialidade, "vem sendo realizada através de conquistas de parcelas de terras".

Martins (2004) não desconsidera fatores outros, como as relações e/ou os discursos invocando relações de parentesco (reais ou não, como diria Keyes [1976]) e a religiosidade, ambos muitas vezes associados ao elemento político, atentando ainda para a estreita relação mantida por esses coletivos com o Estado por meio dos "órgãos tutores" como a FUNAI, a qual, em sua visão, "constitui a marca que condiciona a especificidade das inter(rel)ações e interdependências existentes no campo político intersocietário" (Martins, 2004:227-228).

O sistema nativo nesse caso [afirma a autora], por tratar de população não diferenciada em termos de traços culturais do ambiente regional, passou a ser marcado pela diferenciação entre os assistidos $e$ as populações não reconhecidas oficialmente ou tuteladas pelo Estado. É esse fato que marca e legitima a continuidade e o rearranjo de toda uma nova forma de ser, relacionada à produção de uma indianidade em um nível local/regional/nacional. 
Quanto aos índios Potiguara, as análises não fogem desse contexto teórico. Para Azevedo (1986) e Palitot (2005, 2008), a díade Estado/luta pela terra

formou a base para o advento de uma "identidade étnica" do grupo. Isso porque, na luta para conferir legitimidade à posse do território pelos índios, estes tiveram de acionar discursos demarcando sua diferença em relação aos demais atores com os quais tinham de conviver na região onde viviam e atualizar o passado de dominação e resistência por eles experienciado (Azevedo, 1986:41-42).

Segundo Palitot (2008:4-9), antes da mobilização para terem garantido o acesso irrestrito ao território por eles ocupado, muitos potiguaras "escamoteavam" sua identidade étnica. De acordo com ele, foi a luta pela terra que ensejou uma "emergência étnica, articulando novos sentidos e práticas a velhas memórias silenciadas durante séculos de repressão". Por essa razão, a configuração desse coletivo étnico traduz-se a partir de elementos de natureza econômica, política, cultural e moral, bem como nas suas relações com o Estado (cf. Palitot, 2005).

Analisando os discursos de meus interlocutores, tem-se que a fonte "primordial" da indianidade era a descendência, isto é, o fato de terem ambos os genitores como indígenas. Isso pode ser ilustrado pela fala de Orlando, um interlocutor de 36 anos, morador da cidade:

Ser índio pra mim tá no sangue. Índio é aquele que respeita a sua cultura, que vivencia, que valoriza a cultura Potiguara. E, acima de tudo, tá na família. Se seu pai e sua mãe é índio, você também é. Você pode até querer negar. Mas índio, pra mim, é sangue. Tá no sangue. E o não índio é você não ter herança genética indígena. Nem pai nem mãe. Você pode até respeitar, mas se você não tem sangue indígena, a gente agradece, respeita, mas, infelizmente, no meu ver, ser índio tá no sangue. 
Orlando, contudo, não foi o único a acionar o fator "genético" a partir do qual a identidade indígena era elaborada, o mesmo sendo observado nos discursos de outros entrevistados. Ao que tudo indica, tal fenômeno se faz presente não apenas entre os Potiguara, mas também no contexto de outras populações indígenas no Nordeste brasileiro. No caso dos índios Tremembé no Ceará, por exemplo, Valle (2004:320-323, ênfase no original) observou que, para muitos de seus informantes, "o sangue 'refinado' do índio [tinha] uma espécie de 'pureza' biogenética, [sendo] substantivado por sua integralidade, totalizando a natureza do índio puro/mesmo/legítimo". Citando Schneider (1968), o autor atenta para o fato de que tal substantivação, porém, "não deixa de ser culturalmente construída, sobretudo em uma dimensão simbólica".

Entretanto, ainda que a ideia sobre a "quantidade" ou "pureza do sangue indígena" funcionasse como o principal parâmetro por meio do qual a identidade étnica era definida ou interpretada, outros fatores como o local de nascimento e/ou moradia e o maior ou menor contato com índios eram acionados ora para realçar o componente étnico, ora para obscurecê-lo. Murilo, por exemplo, um jovem de 21 anos, por ser filho de um índio e uma branca, se autodefinia como misturado. A noção de mistura no contexto pesquisado dava margens para leituras $e$ identificações variadas quanto ao elemento étnico. No caso de Murilo, a balança pendia favoravelmente para sua autoidentificação como índio. Para tanto, ele recorria ao fato de morar em uma aldeia e de conviver com índios: "Então eu acho que o meu lado tá mais pra ser parte de índio". Claudiano, outro interlocutor de 32 anos, morador da cidade, exemplificava com ainda maior clareza esse fato. Embora fosse filho de brancos, Claudiano dizia:

É como se eu já fosse um índio. Até porque eu já conheço seus costumes, suas tradições. Até por morar aqui, por ter nascido aqui, eu sei de todo o processo indígena, da luta, da preservação, da questão cultural, da questão ambiental. 
Mesmo eu não tendo a "característica indígena" - que eu não tenho -, e mesmo não tendo a etnia indígena - que eu não carrego -, mas eu me sinto como índio. Mesmo não sendo, eu me sinto indígena.

Contudo, nem o fato de um indivíduo ter ambos os genitores classificados como "índios puros", tampouco nascer $e$ viver em uma determinada aldeia e, portanto, manter-se em estreito contato com indígenas, implicavam necessariamente numa autoidentificação como índio. Vejamos outros dois casos: Luiz, um jovem de 17 anos, filho de índios, que nasceu e sempre viveu numa determinada aldeia, não gostava de ser identificado como índio e simplesmente se recusou a discutir comigo sobre esse marcador de sua identidade. Já Scarlett, uma travesti de 23 anos, tinha mãe índia e pai "branco" e morou durante a maior parte de sua vida em uma aldeia. Porém, diferentemente de Murilo, ela dizia não se "sentir" índia, "me sinto mais uma pessoa da cidade. Porque eu não tenho os hábitos indígenas, os costumes de se vestir, dançar, falar as línguas... não tenho".

As razões para enfatizar o componente indígena, para rechaçá-lo ou ao menos reduzir sua importância na construção das identidades das pessoas com quem convivi foram diversas $e$ variaram de acordo com cada interlocutor, de modo que não haveria espaço aqui para deslindá-las todas. Assim, poderíamos atribuir esquematicamente tal fenômeno a uma instância eminentemente individual dos sujeitos, isto é, ao desejo de ser reconhecido como o "eu" que se pretende ser (Butler, apud França, 2007:252). Por outro lado, sem desconsiderar essa interpretação, havia uma outra razão mais pragmática que levava certos sujeitos a realçarem ou renunciarem à sua indianidade. Refiro-me aos interesses políticos em jogo. Rômulo, por exemplo, um interlocutor de 26 anos, morador da cidade, embora se dissesse "mestiço" e "aculturado", investia no discurso étnico e atuava no movimento indígena mais assiduamente do que muitos de meus interlocutores que se diziam índios "legítimos". Graças a isso, "hoje, diante do 
meu povo, existe um certo respeito comigo, por conta do trabalho que eu tento desenvolver com a comunidade".

\section{Segundo marcador: homossexualidade}

Se a questão étnica apresentava grande fluidez $e$ variabilidade nos discursos e na agência das pessoas ouvidas, a maneira como definiam a homossexualidade emergiu de modo mais padronizado e homogêneo. Para a grande maioria delas, a noção de homossexualidade não apenas era conhecida, mas era acionada na constituição de um universo de significados referentes aos comportamentos e identidades sexuais. Mesmo no caso de cinco travestis, foi empregada a categoria "homossexual" autorreferencialmente.

Por meio de "mexericos, calúnias, maledicências, insultos, elogios, acusações, críticas, polêmicas, louvações" (Bourdieu, 1996:81), a homossexualidade era elaborada por meus interlocutores. Não obstante as variações semânticas e biográficas, em linhas gerais, para eles, essa palavra dizia algo de suas identidades, as quais começaram a ser construídas a partir mesmo do "nascimento": "A gente nasce homossexual". Tal percepção ganhava vida nas reminiscências, quando os sujeitos retornavam a uma infância povoada por brincadeiras, por sensações ainda sem nome e pela convivência (nem sempre harmoniosa) com os pais. O sentimento de "diferença", portanto, nascia aí, não muito tempo depois dos sujeitos. Simões (2004:432-433) observa que muitos homossexuais constroem uma "trama que estrutura os acontecimentos numa narrativa mais ou menos coerente, capaz de oferecer um senso de continuidade de si e do lugar social".

Assim, interpretada como um aspecto intrínseco ao "eu", a homossexualidade não deixava de ser criativamente elaborada pelos sujeitos diante de um corpus de sensibilidades - a dor, o sofrimento, desejos incompreendidos, sensações corpóreas, prazeres -, mas também no âmbito da relacionalidade. Neste segundo caso, era na tensão com os pais, nos comentários e nas reações de outros familiares, de colegas da escola, de pessoas 
conhecidas na aldeia ou na cidade, na convivência com um grupo de pares e nas relações eróticas e/ou afetivas com pessoas do mesmo sexo - as quais poderiam ser um primo, um tio, um vizinho, geralmente mais velho - que se dava a percepção de uma sexualidade não heteronormada. $\mathrm{O}$ insulto aqui cumpria um papel central. A partir dele se veiculava a mensagem de que esses indivíduos possuíam uma "dada qualidade", de que eles deveriam comportar-se "em conformidade com a essência social que lhe[s] é assim atribuída" (Bourdieu, 1996:82).

Mas em que consistia tal "qualidade"? O desejo não poderia ser, tão abstrato, invisível. Ora, a "qualidade" era traduzida nos atos, nas "brincadeiras de menina", no "jeitinho", ou seja, nas performances de gênero: uma "abominação" de caráter individual visível nos corpos (Goffman, 1988:14), cobrando dos sujeitos um "cuidado de si" (Foucault, 1985:50) constante. Porque tal escrutínio advinha das reações dos outros, o peso das práticas sexuais per se era relativo. Afinal, embora a "gramática da passividade/ atividade" (Carrara; Vianna, 2004) estivesse presente nos discursos da grande maioria dos personagens ouvidos, não era a prática sexual que demarcava a fronteira entre um "homem pela metade" (homossexual) e um "homem mesmo" (heterossexual). As falas de meus interlocutores levavam-me ao encontro das considerações de Leal (2005:73), para quem

[a] classificação das práticas [sexuais] demonstra que as restrições devem ser contextualizadas, pois são relativas a um determinado momento ou ao modo como um parceiro está sendo posicionado ou pensado naquela relação.

As informações etnográficas, portanto, me faziam crer que o engessamento das práticas sexuais em dicotomias estanques ("passivos" versus "ativos"; "femininos" versus "masculinos"; "dominados" versus "dominadores") era insuficiente para distinguir as identidades sociossexuais dos sujeitos. Para além delas, estavam as performances de gênero, a "escolha do objeto 
sexual" (cf. Ford, 1995), as emoções atreladas a tal objeto e, acima de tudo, a maneira como cada ator interpretava essas questões.

Por sinal, as fronteiras sociossexuais pareciam borradas quando estava em jogo a maneira como cada um interpretava o desejo sexual homoerótico. Obviamente, a percepção de que a atração erótica se dava em relação a indivíduos do "mesmo sexo" e não do "sexo oposto" era crucial para suas (auto)representações na "qualidade" de homossexuais. Por outro lado, para muitos, os "homens mesmo" praticavam sexo com "homens pela metade" porque "gostavam". Nesse sentido, à primeira vista o elemento "desejo" estaria presente em quaisquer sujeitos do sexo masculino, independentemente de suas identidades sociossexuais. Diante disso, o que diferenciaria uns dos outros? Em primeiro lugar, ao contrário dos homossexuais, os "homens" não sofreram o mesmo processo de rotulação que aqueles. Confiando nos relatos de meus interlocutores, eles não brincaram de boneca quando crianças, não tinham trejeitos femininos $e$, consequentemente, não foram socializados sob advertências $e$ censuras, o que ensejaria o sentimento de que eram "diferentes". 3 Desse modo, os "homens mesmo" sabiam que estavam interagindo sexualmente com "homens pela metade", e isso os mantinha numa zona de relativo conforto. Além do mais, o desejo homoerótico não era experienciado do mesmo modo por uns $e$ outros. Para os homossexuais, tal desejo era sentimentalizado;

3 "Numa cultura tradicionalmente patriarcal e machocêntrica como é a brasileira", escreve Guimarães (2004:44-45), "um dos fatores a ser destacados é a nítida dicotomização entre os papéis sociais - e de gênero - masculinos $e$ femininos. Esta delimitação simbólica de fronteiras entre os sexos se reproduz nas atividades socializadoras do cotidiano, não somente na produção de atitudes $e$ comportamentos como também na determinação de atividades e de espaços sociais 'próprios' a cada sexo. (...) No sistema classificatório referente à sexualidade, a categoria homossexual (masculino e feminino) tem a categoria heterossexual como referencial básico de normalidade, mas obedece a uma lógica cruzada e invertida de construção. Isto é, os elementos componentes da categoria homossexual masculino são emprestados da categoria heterossexual feminino - configurando, nesta construção, categorias anômalas, intersticiais e negativamente sancionadas". 
havia uma demanda por carinho, amor, respeito, troca, companheirismo, cumplicidade. Quanto aos "homens", o desejo não era regido pelos mesmos imperativos ${ }^{4}$, tampouco apresentava o mesmo grau de frequência e intensidade. Ou seja, as trajetórias sexuais/afetivas dos indivíduos também atuavam como demarcadores identitários. Os "homens mesmo", ainda que interagissem homoeroticamente em diferentes fases de suas vidas, se relacionavam pública e predominantemente com mulheres. Para muitos deles, portanto, as relações homoeróticas eram tidas como experiências fortuitas e superficiais, o desejo sexual por mulheres $e$ a performance de gênero resguardando suas masculinidades e distanciando-os dos homossexuais. ${ }^{5}$ Em linhas gerais, a distinção entre "homens pela metade" e "homens mesmo", por conseguinte, passava por vetores variados, interdependentes e, acima de tudo, situacionais, como a) atividade e trajetória sexual; b) desejo erótico; c) orientação sexual; d) performances de gênero; e) agência pessoal.

Ter em mente esse contraponto nos permite visualizar o quão dependente da relacionalidade são as identidades. A despeito da dicotomia entre "homens pela metade" $e$ "homens mesmo", porém, havia um caleidoscópio de experiências e

${ }^{4}$ Certamente os discursos antissentimentalizantes emitidos pelos "homens" não apenas por meio de palavras injuriosas, mas também por suas atitudes cotidianas e gestualidades - estavam relacionados à problemática concernente à construção das masculinidades. Alguns estudiosos dessa temática (cf. Gutmann, 1997; Welzer-Lang, 2001) observam que a masculinidade, longe de ser um atributo dado e permanente, é um constructo social extremamente complexo e dinâmico. Vale de Almeida (1995:17, 59, 66-69), por exemplo, observa que, dada sua precariedade, a masculinidade tem de ser continuamente reiterada por meio da "incorporação, da ritualização das práticas da sociabilidade cotidiana e de uma discursividade que exclui todo um campo emotivo considerado feminino". Nesse sentido, o domínio do corpo, das emoções e sentimentos se dá paralelamente a um contraponto não linear com a feminilidade $e$ no estabelecimento de hierarquias entre os mais e menos homens.

${ }^{5}$ A fluidez nas relações sexuais e homoeróticas, contudo, não implicava na incolumidade das masculinidades dos "homens mesmo" (cf. Sell, 1987; Murray, 1995). 
representações instaurado pelos sujeitos engajados em interações homoeróticas. Extrapolando atividades sexuais, genitálias, fantasias, desejos sexuais e os comportamentos dos sujeitos"; compreendendo "personalidade[s], sentimento[s], sensaç[ões]; os limites, o pensar, o sentir, as convenções, o conhecer-se e as conexões sociais" (Pasini, 2009:244), vemos que "a homossexualidade não reflete uma ideologia ou uma prática, mas fragmenta-se em múltiplas modalidades particulares, segundo os momentos e espaços distintos de uma mesma realidade histórica" (Guimarães, 2004:39, ênfase no original). Nesse sentido, levando em conta os vocabulários ou práticas linguísticas, que "criam ou reproduzem subjetividades diversas" (Costa, 1992:14-15), observamos um universo simbólico construído polissemicamente. Prova disso foram as diversas outras categorias acionadas pelos atores mais ou menos aproximadas à noção de homossexualidade, tais como "bicha", "fresco", "frango", "viado", "gay", "entendido", "biba". 6 Os campos semânticos dessas palavras se sobrepunham, de modo que as elas apareciam sinonimicamente.

Nesse sistema classificatório, elaborado contrastivamente, também havia os "homens", "homens de verdade", "homens mesmo", "bofes", "boys", "boyzinhos", "machos", designativos dos indivíduos com quem interagiam ou poderiam interagir sexualmente, os quais se contrapunham aos "homossexuais", "gays", "entendidos", "bichas", "viados", "frescos", "frangos", "bibas". Até mesmo quando referidas à anatomia dos corpos e às práticas sexuais, as palavras criavam e traduziam relações, aludiam a um corpus de ações e contra-ações prazerosamente engendradas num universo sensível construído pelos sujeitos. A depender dos contextos interativos (formais ou informais), dos

6 Green (2000) procura historicizar os significados dos termos "fresco", "puto", "homossexual", "viado", "bicha", "entendido" e "gay" a partir das visões médica, criminalista e dos próprios atores homossexuais nas cidades do Rio de Janeiro e São Paulo ao longo do século XX. A respeito de algumas dessas categorias, ver ainda Fry (1982a e b); Fry; MacRae (1983); MacRae (1990), Parker (1991); Guimarães (2004); Kulick (2008). 
atores envolvidos (homossexuais e/ou não homossexuais), de seus status sociais, de suas idades e níveis de escolaridade, de acordo com a natureza dos vínculos relacionais (eróticos/afetivos, de amizade ou inimizade) criados por e entre eles, os sentidos dessas palavras variavam. Respeito/desrespeito, afirmação/negação, jocosidade/discriminação eram alguns dos elementos que entravam em jogo, situacionalmente, quando o assunto em questão eram as sexualidades, masculinidades e feminilidades. Atentar para essa diferença, às vezes bastante sutil, permitia observar a ocorrência de estratificações e hierarquizações de ordem sexual e social, hierarquias operadas não apenas em termos duais ("homens pela metade" versus "homens mesmo"), mas entre "homens" e "homens", "homossexuais" $e$ "homossexuais". As assimetrias aqui, porém, não negavam necessariamente a reciprocidade; afinidades não solapavam diferenças; o desejo não subjugava a cruel injúria; a amizade não apagava conflitos. Em suma, também nesse contexto "as relações, antes de homogêneas, [eram] engendradas, construídas, expandidas, anuladas em termos de interseções e sobreposições" (Wolf, 2003:321).

Mas qual o papel que a etnicidade desempenhava quando articulada à homossexualidade aqui? Uma vez mais, tal intersecção variava segundo cada indivíduo. Jennifer, uma travesti de 26 anos, moradora de uma aldeia, ainda que admitisse o preconceito contra homossexuais de um modo geral e contra ela em particular, afirmava que o fato de ela ser indígena a protegia de demonstrações mais explícitas e violentas de intolerância. Nesse sentido, sua identidade étnica atuava como uma blindagem sem a qual ela ver-se-ia ocupando uma posição muito mais vulnerável. Todavia, o caso de Jennifer foi o único em que a etnicidade se articulava favoravelmente à homossexualidade, pois na maioria dos casos tal articulação se dava negativamente. Rômulo, a quem já me referi, dizia ser visto por muitas lideranças indígenas como alguém sem "caráter", o que ele atribuía à maneira como sua sexualidade era representada no contexto onde vivia. Pablo, um jovem de 22 anos, que se autodefinia como 
"descendente" de índios e morava em uma aldeia, afirmava que alguns caciques simplesmente recusavam-se a admitir a existência de homossexuais indígenas. Para esses dois interlocutores, "as pessoas que tão na autoridade são muito machistas, homofóbicas, então isso gera uma confusão". Consequentemente, ambos acreditavam que o fato de serem homossexuais interferia negativamente em suas trajetórias e aspirações políticas, bem como na sua inserção nos postos de trabalho disponíveis nos lugares onde moravam.

Discursos como os emitidos por Rômulo e Pablo mostram que o cruzamento entre etnicidade e homossexualidade se dava numa tensão potencialmente disruptiva. Ou seja, segundo uma visão etnicista heteronormativa, para alguns era necessário separar as duas coisas. Mas ainda que as falas desses dois interlocutores ilustrassem parcelas da realidade na qual estavam inseridos, isso não refletia a realidade em sua totalidade. Para algumas das pessoas ouvidas, a equação entre o "ser" índio e homossexual tinha como resultado atributos físicos e performativos favoráveis. Para eles, os índios, via de regra, eram mais "fogosos". Quanto aos homossexuais indígenas, tal qualificativo se somava ao fato de serem mais "femininado" $e$ "carinhosos" que os não índios, se "emperiquitavam" e "rebolavam" mais, vestiam roupas de mulher e gostavam de "se divertir". Vemos então, nesses recortes discursivos, um processo de sexualização e generização étnico, ao menos referente aos homossexuais indígenas. Consequentemente, na economia dos afetos e prazeres, estes últimos levariam vantagem sobre os não índios, despertando a "atração" dos brancos "pela maneira de ser, pela maneira de agir" (Murilo).

As representações explicitadas por esse tipo de formulação discursiva no que diz respeito à articulação entre indianidade e homossexualidade, embora válidas e importantes, não constituíam, no entanto, a regra. Na verdade, para a maioria dos entrevistados, o fator étnico não repercutia absolutamente no fator sexual: 
Homossexual é homossexual. Independente de raça, povo, etnia, crença, cultura. Não tem diferença de homossexual A ou homossexual B. Todos os homossexuais buscam o mesmo padrão de vida. Não são pessoas que estão paradas no tempo. Eles buscam renovações, buscam conhecimentos (Claudiano).

Eu acho que diferença não existe. Eu acho que nada indígena é diferente, por mais que exista diferença no meio. Não existe diferença entre o índio e o que não é índio. Isso aí não tem nada a ver, é gay do mesmo jeito. O que um faz, o outro faz (Britney).

\section{Terceiro marcador: religião}

Os excertos acima transcritos traduzem uma percepção não etnicista da homossexualidade presente nos discursos e na vida cotidiana de boa parte de meus interlocutores. Ou seja, para muitos deles, a questão étnica não repercute de modo significativo em suas formas de viver e conceber suas trajetórias e identidades sexuais. Por outro lado, um terceiro marcador emergiu com muito mais força associado à questão homossexual. Refiro-me à religião como crença individual, porém apreendida socialmente, e como instituição.

Para entender esse fenômeno, é preciso ter em mente aspectos de ordem histórica que redefiniram ao longo do tempo a organização social não apenas da coletividade Potiguara, mas também das demais etnias indígenas situadas na região nordeste do Brasil. Ao longo dos séculos XVII e XVIII, a Igreja Católica, em suas variadas denominações (clérigos, capuchinos, beneditinos, carmelitas), atuou junto a essas populações no intuito de catequizá-las e, acima de tudo, geri-las (cf. Dantas et al., 1992). A interferência da Igreja Católica gerou consequências que se fizeram sentir não somente nos séculos seguintes, mas também no presente. No caso potiguara, esse fenômeno é comprovado pelo fato de o catolicismo, a partir de um elaborado processo de ressignificação, ser tomado como fonte da própria etnicidade (cf. 
Barcellos, 2005; Palitot, 2005). Como demonstração disso está o fato de em praticamente todas as aldeias haver uma igreja e seu respectivo santo padroeiro. A partir dos anos de 1960, também se deu a inserção na área indígena de religiões pentecostais como Batista, Betel, Assembleia de Deus, Igreja Universal do Reino de Deus, Brasil para Cristo, Testemunhas de Jeová, entre outras. A presença do pentecostalismo, seguindo uma tendência observada em todo o Brasil, vinha crescendo exponencialmente na região habitada pelos índios.

A maneira como as religiões cristãs era interpretada pelos atores potiguara, contudo, apresentava matizes variados. Um de meus interlocutores, por exemplo, que não estava entre os homossexuais que conheci e que se definia como "católico", ponderava:

Eu sigo a Igreja Católica. Só que, em primeiro lugar, está minha cultura indígena. Porque a gente, antes de qualquer religião (católica, evangélica), a gente temos nossa religião como indígenas. Eu não vou deixar de seguir minha cultura por causa de uma religião. Eu fui batizado na Igreja Católica. Isso porque nossos povos mais velhos seguiam muito a religião católica, eram muito devotos, mas isso já vem por eles serem obrigados. Então nossos antepassados eram obrigados a seguir a religião católica. Naquele tempo o povo ficava entre a cruz e a espada: ou você era religioso ou você morria. Então é por isso que eles seguem hoje a religião (Toninho).

Dizia outro entrevistado:

Também faço parte da católica. Tenho a mentalidade de dizer que sou católico hoje, mas sabendo que antes do catolicismo chegar no povo potiguara, existiam já as nossas danças, o nosso ritual, e o nosso modo de fazer orações, de suplicar a um deus, esse deus que é Tupã, que é um deus criador. Eu acho que hoje eles [os "brancos"] têm que respeitar as nossas tradições, os nossos costumes. Porque a nossa religião está presente desde o tempo de nossos 
ancestrais. Quando [os "brancos"] viam os índios fazendo seu ritual, imaginavam que eles estavam incorporando o demônio. Viram uma coisa totalmente diferente. Não sabendo eles que a gente tem nosso próprio deus, que é o deus criador, assim como eles têm (Riobaldo).

Eu acho que o índio não era pra ter religião cristã, e sim a religião própria dele, a religião de vivência. Porque antigamente não existia catolicismo, antigamente não existia os protestantes, e sim a religião cultural, que é a nossa. O catolicismo massacrou nossos povos, e hoje, pela minha visão, eu acho que eles voltaram atrás como se fosse uma desculpa, hoje estão aí como se fosse um modo de pedir desculpas aos povos que foram massacrados (Dimitri).

Essas informações nos auxiliam na compreensão de um quadro social no qual as religiões cristãs desempenhavam um papel importante. Mas o que interessa aqui é entender a articulação que meus interlocutores homossexuais promoviam entre religião e sexualidade. Embora a variável "religião" não constasse como um tópico prioritário por ocasião das entrevistas, sempre procurei saber de cada entrevistado se era adepto de alguma denominação religiosa, de modo que me foi possível descobrir que a maioria dos depoentes homossexuais apontava o catolicismo como a crença que seguiam ou com a qual foram socializados. Dentre eles, alguns se diziam praticantes, enquanto outros não. Cinco entrevistados ou frequentavam, ao tempo de minha pesquisa, templos protestantes (Testemunhas de Jeová, Igreja Universal do Reino de Deus, Betel e Batista) ou chegaram a frequentar em algum momento de suas vidas.

Murilo, a quem já me referi, pretendia tornar-se um homem de negócios bem-sucedido. Tal anseio encontrava suporte em sua adesão religiosa. Ele se dizia "protestante" (ao contrário de seus familiares, que eram todos católicos) e frequentava havia quatro anos a Igreja Universal do Reino de Deus (IURD), na cidade. Segundo ele, a escolha da IURD devia-se à "maneira do pastor 
ensinar. Ele ajuda mais as pessoas a se desenvolver mais, orienta que a gente prospere". Contudo, a crença de Murilo vinculava-se também a outra questão: sua sexualidade. "Às vezes eu vinha da igreja, aí ia dormir com meu primo, a gente fazia certas coisas... Aí eu ficava na minha mente: 'Ai, meu Deus, que pecado! Cheguei da igreja e ia pecar!'. Aí ficava pesado, pedindo a Deus". Já Felipe, um jovem de 18 anos, morador da cidade e "descendente" de índios, afirmava: "Eu era evangélico. Mas eu não sou mais. A religião foi uma escolha minha. Eu tinha uns 14 anos quando eu entrei pra igreja". Segundo ele, seus pais o incentivaram muito a perseverar na religião, acreditando que assim ele se afastaria das "más influências". Entretanto, passado algum tempo, Felipe deixou de frequentar a igreja "porque eu descobri que eu sou homossexual, aí isso tudo mexeu com a minha cabeça e eu acabei saindo da igreja. Aí, com tudo isso, eu sempre ouvia na igreja o pastor falar que não é permitido".

Felipe acreditava que "ser" homossexual era um "pecado", enquanto Geraldinho (que era católico e "descendente" de índios) a via como um "dom" ou "castigo" divino:

É porque antigamente, na Bỉblia, não existia esses tipos de pessoa. Porque Deus fez Adão pra Eva, Eva pra Adão. E através dessa homossexualidade, surgiu o povo fazendo safadeza. Mas eu acho que não é safadeza, é um dom, um castigo. Na Biblia a gente tem um castigo, porque o homem nasceu pra mulher, a mulher nasceu pro homem... Eu acho que é um castigo pra gente, né? Porque não é que eu queria ser, não. Eu acho que a espécie da gente é a mais castigada: a mulher com outra mulher e o homem com um homem. Porque naquela época não existia essas coisas.

Também interessante é o caso de Orlando, pois embora realçasse sua identidade étnica, não era a indianidade que mantinha uma relação tensionada com sua sexualidade, mas sim a religião. Católico praticante, Orlando não concebia a homossexualidade como uma "doença". Mesmo assim, prevalecia em seu discurso (ora velada, ora explicitamente) uma 
representação segundo a qual a homossexualidade constituía um problema. Certa vez, quando conversávamos informalmente, Orlando afirmou que, de todos os seus "vícios" (beber, fumar, frequentar bares), o único do qual ele ainda não havia conseguido se "libertar" era justamente a homossexualidade. Já Luiz dizia "não foi culpa minha de eu ser homossexual. É coisa do destino mesmo que acontece". Também católico praticante, todos os dias Luiz ia à igreja da aldeia. Era ele quem a mantinha limpa $e$ arrumada. Um dia ele decidiu procurar um padre para confessarse e resolver as angústias suscitadas por sua sexualidade.

Quando eu fui me confessar com o padre, aí eu perguntei a ele: "Por que a gente é desse jeito?". Aí ele falou que é quando a mãe tá gestante, aí a criança recebe mais hormônio feminino do que o masculino. Aí eu já me conformei mais. Porque todo mundo tem seu jeito de ser, né? Tem o livre-arbítrio. E vive da maneira que Deus quiser. E se nasceu assim, tem que morrer assim.

Fábio, um jovem de 26 anos, morador de uma aldeia, filho de um casal de índios e católico praticante, dizia:

Eu não queria ser um homossexual, eu queria ser uma mulher de verdade, pra ter meus filhos, chegar a me casar. Mas eu não tive essa chance. $\mathrm{O}$ meu caminho tá traçado. Não sei por que, só Deus sabe explicar. Eu sei que na Bíblia está escrito: "O homem nasceu para a mulher, não nasceu para outro homem". Mas eu me pergunto: "Senhor, por que o Senhor me deu esse destino? Por que eu nasci desse jeito? Eu tô pagando por quem? Alguma pessoa da minha família fez alguma coisa ruim pra eu estar pagando isso até o fim da minha vida?". A Igreja Católica eu amo de verdade. Eu amo, eu dou minha vida. Mas só que lá dentro tem pessoas que não aceitam.

Esses enunciados apresentam a articulação entre religião como crença pessoal e homossexualidade. Tal articulação, como podemos observar, se dá negativamente, ou seja, numa tensão 
entre os dois marcadores sociais. Nesse sentido, lida sob a ótica religiosa, a homossexualidade é definida como "pecado", "castigo", em suma, como um aspecto problemático, um erro, um fardo. Curiosamente, esse fato parece conter certa correspondência na maneira como alguns de meus interlocutores interpretam o papel da religião, dessa vez na qualidade de instituição. As palavras de Pablo ilustram isso. Para ele, que tinha o projeto de fundar uma ONG local em defesa dos direitos homossexuais, a Igreja Católica emergia como o maior empecilho: "A Igreja Católica não vai permitir. Eu acredito que a religião é que toma a frente aqui e o que eles dizem é o que deve ser cumprido".

Um aspecto adicional, ainda envolvendo a articulação entre religião e homossexualidade, surgiu no decorrer do trabalho de campo quando me deparei com dois interlocutores adeptos da "umbanda". A relação entre homossexualidade e cultos afrobrasileiros é objeto de investigação no Brasil pelo menos desde os anos 1940, a partir do trabalho desenvolvido por Landes (2002) em terreiros da Bahia. Nas décadas seguintes, muito se escreveu a respeito disso (cf. Fry, 1977, 1982a; Matory, 1988; Wafer, 1991; Birman, 1995; Moutinho, 2005), porém, não sendo possível escrutar aqui esse tema, valeria a pena ao menos considerar um dado apontado por Birman (2005:404-405), referente aos "comportamentos 'pouco convencionais' [desviantes em termos sexuais e de gênero] (...) dos médiuns (...) [n]esses cultos", pois é nesse contexto, conforme a autora, que se dá a "valorização" das dimensões de gênero e sexualidade, que muitas vezes transgridem as "normas conjugais e familiares". Nesse sentido, no cenário por mim investigado, provavelmente não era mera coincidência o fato de que as únicas pessoas a mencionarem diante do etnógrafo, de forma elogiosa ou demonstrando curiosidade os cultos afrobrasileiros, serem homossexuais.

Uma particularidade presente no modo como os "umbandistas" homossexuais articulavam crença e sexualidade e que portanto os diferenciava daqueles que se definiam como "católicos" ou "evangélicos" - residia no fato de não haver um 
conflito entre um marcador e outro de suas identidades. Talvez isso pudesse ser explicado porque, ao contrário de outras denominações religiosas, os cultos afro-brasileiros constituem um campo menos hostil $e$ mais receptivo para homossexuais $e$ pessoas que agenciam sexualidades menos "convencionais" (cf. Santos, 2008:149). Todavia, se, ao nível pessoal, crença $e$ homossexualidade harmonizavam-se nesse caso específico, no âmbito social ser identificado como adepto de alguma religião de matriz afro tinha por consequência uma dupla estigmatização, o que não era de se estranhar, dado o predomínio das religiões cristãs na região, conforme foi dito. $\mathrm{O}$ fato de um de meus interlocutores umbandistas afirmar que tinha de enfrentar dois tipos de preconceito - um contra sua sexualidade, outro, contra sua crença - é ilustrativo disso. Porém, uma vez mais, aparentemente o componente étnico ali não desempenhava nenhum papel relevante.

\section{Considerações finais}

$\mathrm{O}$ que motivou a minha pesquisa foi o esforço de entender as possíveis conexões entre etnicidade (o "ser índio") e homossexualidade. Haveria discursos, comportamentos, práticas, representações em torno da homossexualidade que, relacionadas à indianidade, diferenciar-se-iam de modo significativo daqueles observados em contextos "não indígenas"? A resposta a que nos conduz o exposto neste artigo é: não. Tanto a minha observação quanto os depoimentos fornecidos por meus interlocutores caminharam no sentido de uma indistinção categórica quando tomada como parâmetro a contraposição entre homossexuais indígenas e não indígenas. O vocabulário que acionaram, as histórias de vida, os processos de rotulação dos quais eram alvo, as trajetórias sexuais e afetivas, as performances de gênero, a maneira como interpretavam a própria sexualidade não erigiam um processo de fronteirização claro e rígido entre "brancos" $e$ índios. Poderíamos elencar uma série de razões para explicar esse fato. Em primeiro lugar, de modo geral, os Potiguara, bem como 
as demais populações indígenas situadas na região nordeste, não apresentam em seus padrões culturais uma divergência em relação aos padrões observáveis na sociedade envolvente. Ou seja, repetindo uma frase de Pacheco de Oliveira (1999:99), as primeiras apresentam um "baixo grau de distintividade cultural". Outra razão poderia ser encontrada no próprio significado da noção de etnicidade. Conforme mostrei na primeira parte deste artigo, a questão étnica constitui acima de tudo um artifício político. Ou seja, para aqueles indivíduos sem qualquer interesse em atuar no movimento indígena $e$, por conseguinte, em enfatizar sua identidade étnica, certamente a indianidade não irá desempenhar nenhum papel (ou o desempenhará de forma bastante atenuada) na vivência homossexual e em como ela será lida pelo "eu". O fato de alguém realçar sua indianidade, recusála, invocá-la em determinadas situações e em outras não, porém, depende não apenas de interesses políticos, mas também dos desejos, de fatores objetivos, reflexivos, cognitivos e emocionais de cada indivíduo. São essas variáveis que nos permitem entender porque certos indivíduos investem tanto em sua indianidade, enquanto outros procuram dela se afastar.

De todo modo, o fato é que se, na maioria dos casos, o fator étnico não exerce uma função simbólica e representacional relevante no modo como alguns atores interpretam suas sexualidades, a religião, na qualidade de crença e como instituição, emerge recorrentemente nas falas de muitos dos entrevistados. Certamente esse fenômeno pode ser explicado se levarmos em conta que sexualidade e religião constituem "campos interrelacionados, os quais entram no esquema de morais socioculturais contextualizadas" (Scott, 2007:13-14). A articulação desses campos de experiência se dá pelos agentes locais, pelas redes de sociabilidade e pela família. Nesse sentido, tanto a família quanto a religião implicam "novas formas de funcionamento, possibilitando ordenações as mais diversas" (Heilborn et al., 2005:10-11). Tanto a sexualidade quanto a religião (na qualidade de crença individual e/ou coletiva) terminam por "modelar" "a subjetividade dos sujeitos, conduzindo a distintas formas de 
percepção e de vivência do mundo e das relações sociais, que são continuamente reelaboradas no fluxo da experiência social" (Natividade, 2005:248).

Ao considerar tal perspectiva teórica, torna-se mais fácil entender a primazia que o marcador religioso apresenta, em detrimento do étnico, no modo como os meus interlocutores elaboram suas experiências e identidades sexuais. Entretanto, vale dizer que se trata de uma questão de ênfase e não de mera substituição de um marcador por outro. Ou seja, embora em termos comparativos e analíticos a religião tenha maior peso que a etnicidade em sua articulação com a homossexualidade, não podemos afirmar que um fator automaticamente oblitera o outro. Primeiro porque, como vimos, a questão étnica está presente em alguns casos. Segundo porque, no contexto pesquisado, havia uma articulação complexa envolvendo religiosidade e etnicidade, ora simbiótica (quando a primeira foi acionada como suporte simbólico da segunda), ora conflitiva (quando as religiões cristãs foram interpretadas como uma instância imposta aos indígenas $e$ que têm por finalidade deslegitimar os valores culturais de uma coletividade etnicamente diferenciada). Em suma, etnicidade, homossexualidade e religiáo, ainda que constituíssem campos de experiência relativamente autônomos, não deixaram contudo de articular-se. Mas tal articulação variou enormemente, o que dependeu dos atores ouvidos, de suas peculiaridades biográficas, da posição ocupada por cada indivíduo no campo político $e$ simbólico instaurado pela etnicidade, além do tipo e do grau de adesão religiosa do sujeito em questão.

\section{Referências bibliográficas}

ARONSON, Dan R. Ethnicity as a Cultural System: An Introductory Essay. In: HENRY, Frances (org.). Ethnicity in the Americas. Paris, The Hague, 1976, pp.9-20.

Azevedo, Ana Lúcia Lobato de. A Terra Somo Nossa: uma análise de processos políticos na construção da terra Potiguara. Dissertação (Mestrado em Antropologia Social), Museu Nacional, UFRJ, 1986. 
BARCellos, Lusival Antonio. Práticas educativo-religiosas dos índios Potiguara da Paraiba. Tese (Doutorado em Educação), PPE, UFRN, 2005.

BARreto Filho, Henyo Trindade. Tapebas, Tapebanos e Pernas-dePau: etnogênese como processo social e luta simbólica. Dissertação (Mestrado em Antropologia Social), Museu Nacional, UFRJ, 1993.

BARRETO FILHO, Henyo Trindade. Invenção ou renascimento? gênese de uma sociedade indígena contemporânea no Nordeste. In: PACHECO DE OliveIRA, João (org.). A viagem da volta: etnicidade, política e reelaboração cultural no Nordeste indígena. Rio de Janeiro, Contra Capa Livraria/LACED, 2004, pp.93-137.

BARTH, Fredrik. Problems in conceptualizing cultural pluralism, with Illustrations from Somar, Oman. In: MAYBURY-LEWIS, David (org.). The Prospects for Plural Societies. Washington, D. C., Proceedings of the American Ethnological Society, 1984, pp.77-87

BARTH, Fredrik. Grupos étnicos e suas fronteiras. In: POUTIGNAT, Philippe; STREIFF-FENART, Jocelyne (org.). Teorias da etnicidade. Seguido de grupos étnicos e suas fronteiras de Fredrik Barth. São Paulo, Fundação Editora da UNESP, 1998, pp.185-228.

BARTH, Fredrik. A análise da cultura nas sociedades complexas. In:__. O guru, o iniciador e outras variações antropológicas. Rio de Janeiro, Contra Capa, 2000, pp.107-139.

BIRMAN, Patricia. Fazer estilo, criando gêneros. Rio de Janeiro, UERJ/Relume Dumará, 1995.

BIRMAN, Patrícia. Transas e transes: sexo e gênero nos cultos afrobrasileiros, um sobrevôo. Revista Estudos Feministas, 13 (2), maioagosto de 2005, pp. 403-414.

BouRDIEU, Pierre. O poder simbólico. Lisboa, DIFEL; Rio de Janeiro, Bertrand Brasil, 1989.

BOURDIEU, Pierre. A economia das trocas linguísticas: o que falar quer dizer. São Paulo, Editora da Universidade de São Paulo, 1996.

CARDoso DE OliveIRA, Roberto. Identidade, etnia e estrutura social. São Paulo, Pioneira Editora, 1976. 
CARdoso de OliveIRA, Roberto. Caminhos da identidade: ensaios sobre etnicidade e multiculturalismo. São Paulo, Editora Unesp; Brasília, Paralelo 15, 2006.

CARRARA, Sérgio; VianNA, Adriana R. B. "As vítimas do desejo": os tribunais cariocas e a homossexualidade nos anos 1980. In: PISCITEllI, Adriana; GREGORI, Maria Filomena; CARRARA, Sérgio (orgs.). Sexualidade e saberes: convençóes e fronteiras. Rio de Janeiro, Garamond, 2004, pp.365-383.

COHEN, Abner. The Lesson of Ethnicity (Introduction). In: COHEN, Abner (org.). Urban Ethnicity. Londres, Tavistock, 1974, pp.ix-xxiv.

COHEN, Ronald. Ethnicity: Problem and Focus in Anthropology. Annual Review of Anthropology (7), 1978, pp.379-403.

CostA, Jurandir Freire. A inocência e o vício: estudos sobre o homoerotismo. Rio de Janeiro, Relume Dumará, 1992.

DANTAS, Beatriz G. [et al.]. Os povos indígenas no Nordeste brasileiro: um esboço histórico. In: CUNHA, Manuela Carneiro da (org.). História dos índios no Brasil. São Paulo, Companhia das Letras/Secretaria Municipal de Cultura/FAPESP, 1992, pp.431-456.

ERIKSEN, Thomas H. The Cultural Contexts of Ethnic Differences. Man, v. 26, n. 1, 1991, pp.127-144.

FORD, Talisman. Passion in the Eye of the Beholder: Sexuality As Seen by Brazilian Sexologists, 1900-1940. Tese (Doutorado em História), Vanderbilt University, 1995.

Foucault, Michel. O cuidado de si. Rio de Janeiro, Edições Graal, 1985. (História da sexualidade, v. 3)

FRANÇA, Isadora Lins. Sobre "guetos" e "rótulos": tensões no mercado GLS na cidade de São Paulo. Cadernos Pagu (28), Campinas, Núcleo de Estudos de Gênero - Pagu/Unicamp, janeirojunho de 2007, pp.227-255.

FRY, Peter. Mediunidade e sexualidade. Religião e Sociedade, n. 1, 1977, pp.105-123.

FRY, Peter. Homossexualidade masculina e cultos afro-brasileiros. In: Para inglês ver: identidade e política na cultura brasileira. Rio de Janeiro, Jorge Zahar Editor, 1982a, pp.54-86. 
FRY, Peter. Da hierarquia à igualdade: a construção histórica da homossexualidade no Brasil. In: Para inglês ver: identidade e política na cultura brasileira. Rio de Janeiro, Jorge Zahar Editor, 1982b, pp.87-115.

FRY, Peter; MACRAE, Edward. O que é homossexualidade. São Paulo, Editora Brasiliense, 1983.

GOFFMAN, Erving. Estigma: notas sobre a manipulação da identidade deteriorada. Rio de Janeiro, LTC Editora, 1988.

GREEN, James N. Além do carnaval: a homossexualidade masculina no Brasil do século XX. São Paulo, Editora UNESP, 2000.

GRÜNEWALD, Rodrigo de Azeredo. Regime de índio e faccionalismo: os Atikum da Serra do Umã. Dissertação (Mestrado em Antropologia), PPGAS/Museu Nacional/UFRJ, 1993.

GRÜNEWALD, Rodrigo de Azeredo. Etnogênese e "regime de índio" na Serra do Umã. In: PACHECO DE OlIVEIRA, João (org.). A viagem da volta: etnicidade, política e reelaboração cultural no Nordeste indígena. Rio de Janeiro, Contra Capa Livraria/LACED, 2004, pp.139-174.

GuimarÃES, Carmen Dora. O homossexual visto por entendidos. Rio de Janeiro, Garamond, 2004.

GutMANN, Mathew C. Trafficking in Men: The Anthropology of Masculinity. Annual Review of Anthropology (26), 1997, pp.385-409.

HEILBORN, Maria Luiza et al. Apresentação: sexualidade, família e ethos religioso. In: HEILBORN, Maria Luiza et al. (orgs.). Sexualidade, familia e ethos religioso. Rio de Janeiro, Garamond, 2005, pp.9-16.

INSTITUTO Brasileiro de Geografia e Estatística - IBGE [www.ibge.gov.br/].

KEYES, Charles F. Towards a New Formulation of the Concept of Ethnic Group. Ethnicity, v. 3, n. 3, 1976, pp.202-213.

Kulick, Don. Travesti: prostituição, sexo, gênero e cultura no Brasil. Rio de Janeiro, Editora Fiocruz, 2008.

LANDES, Ruth. A cidade das mulheres. Rio de Janeiro, Editora da UFRJ, 2002 [1947]. 
LEAL, Andréa Fachel. Práticas sexuais no contexto da conjugalidade: o que implica a intimidade?. In: HEILBORN, Maria Luiza et al. (orgs). Sexualidade, familia e ethos religioso. Rio de Janeiro, Garamond, 2005, pp.61-85.

MACRAE, Edward. A construção da igualdade: identidade sexual e política no Brasil da "Abertura". Campinas, Editora da UNICAMP, 1990.

MARTINS, Silvia Aguiar Carneiro. Os caminhos da aldeia... índios Xucuru-Kariri em diferentes contextos situacionais. Dissertação (Mestrado em Antropologia), PPGAS/UFPE, 1994.

MARTINS, Silvia Aguiar Carneiro. Os caminhos das aldeias XucuruKariri. In: PACHECO DE OliveIRA, João (org.). A viagem da volta: etnicidade, política e reelaboração cultural no Nordeste indígena. Rio de Janeiro, Contra Capa Livraria/LACED, 2004, pp.199-230.

MATORY, Lorand. Homens montados: homossexualidade $e$ simbolismo da possessão nas religiões afro-brasileiras. In: REIS, João José (Org.). Escravidão e invenção da liberdade. São Paulo, Brasiliense, 1988, pp.215-231.

MoUTINHO, Laura. Homossexualidade, cor e religiosidade: flerte entre o "povo de santo" no Rio de Janeiro. In: HEILBORN, Maria Luiza et al. (orgs.). Sexualidade, família e ethos religioso. Rio de Janeiro, Garamond, 2005, pp.273-299.

MURRAY, Stephen O. Machismo, Male Homosexuality, and Latin Culture. In: MuRRAY, Stephen O. (org.). Latin American Male Homosexualities. Albuquerque, University of New Mexico Press, 1995, pp.49-70.

NAGATA, Judith A. What is Malay? Situational Selection of Ethnic Identity in a Plural Society. American Ethnologist, v. 1, n. 2, 1974, pp.331-350.

NATIVIDADE, Marcelo. Homossexualidade masculina e experiência religiosa pentecostal. In: HEILBORN, Maria Luiza et. al. (orgs.). Sexualidade, familia e ethos religioso. Rio de Janeiro, Garamond, 2005, pp.247-272.

OKAMURA, Jonathan Y. Situational Ethnicity. Ethnic and Racial Studies, v. 4, n. 4, 1981, pp.452-465. 
PACHECO DE OliveIRA, João. "O nosso governo": os Ticuna e o Regime Tutelar. São Paulo, Editora Marco Zero, 1988.

PACHECo De OliveIRA, João. A problemática dos "índios misturados" $e$ os limites dos estudos americanistas: um encontro entre antropologia e história. In: PACHECO DE OliveIRA, João. Ensaios em antropologia histórica. Rio de Janeiro, Editora UFRJ, 1999, pp.99123.

PACHECo De Oliveira, João. Uma etnologia dos "índios misturados"? Situação colonial, territorialização e fluxos culturais. In: PACHECO DE OliveIRA, João (org.). A viagem da volta: etnicidade, política $e$ reelaboração cultural no Nordeste indígena. Rio de Janeiro, Contra Capa Livraria/LACED, 2004, pp.13-42.

Palitot, Estêvão Martins. Os Potiguara da Baía da Traição e MonteMór: história, etnicidade e cultura. Dissertação (Mestrado em Sociologia), PPGS/UFPB, 2005.

PALITOT, Estévão Martins. A terra dos índios esquecidos: o processo de territorialização dos Potiguara de Monte-Mór. Trabalho publicado no âmbito do $\mathrm{V}$ Prêmio Antropologia e direitos humanos da Associação Brasileira de Antropologia/Fundação Ford, com o tema "Dilemas da (Des)Igualdade na Diversidade", edição 2008.

PARKER, Richard. Corpos, prazeres e paixóes: a cultura sexual no Brasil contemporâneo. São Paulo, Best Seller, 1991.

PASINI, Elisiane. Sexo com prostitutas: uma discussão sobre modelos de masculinos. In: DíAz-BENíTEZ, María Elvira; FÍGARI, Carlos Eduardo (orgs.). Prazeres dissidentes. Rio de Janeiro, Garamond, 2009, pp.237-262.

POUTIGNAT, Philippe; STREIFF-FENART, Jocelyne. Teorias da etnicidade. Seguido de grupos étnicos e suas fronteiras de Fredrik Barth. São Paulo, Fundação Editora da UNESP, 1998.

SANTOS, Milton Silva dos. Sexo, gênero e homossexualidade: o que diz o povo-de-santo paulista? Horizonte, v. 6, n. 12, Belo Horizonte, PUC Minas, jun. 2008, pp.145-156.

SCHNEIDER, David M. American Kinship: A Cultural Account. Nova Jersey, Prentice Hall, 1968. 
SCOTT, Parry. Morais, religião e sexualidade em contextos urbano, rural e indígena: namoro, aborto e responsabilidade. In: SCOTT, Parry; ATHIAS, Renato; QUADROS, Marion Teodósio de (orgs.). Saúde, sexualidade e familias urbanas, rurais e indígenas. Recife, Editora Universitária da UFPE, 2007, pp.13-54.

Sell, Tereza Abada. Identidade homossexual e normas sociais: histórias de vida. Florianópolis, Editora da UFSC, 1987.

SIMÕES, Júlio Assis. Homossexualidade masculina e curso da vida: pensando idades e identidades. In: PISCITELLI, Adriana; GREGORI, Maria Filomena; CARRARA, Sérgio (orgs.). Sexualidade e saberes: convençôes e fronteiras. Rio de Janeiro, Garamond, 2004, pp.415447.

STOLCKE, Verena. Is Sex to Gender as Race Is to Ethnicity? In: DEL VALLE, Teresa (org.). Gendered Anthropology. Londres, Routledge, 1993, pp.17-37.

VAlE DE AlmEIDA, Miguel. Senhores de si: uma interpretação antropológica da masculinidade. Lisboa, Fim de século, 1995.

VALLE, Carlos Guilherme Octavianno do. Terra, tradição e etnicidade: um estudo dos Tremembé do Ceará. Dissertação (Mestrado em Antropologia), PPGAS/Museu Nacional/UFRJ, 1993.

VALLE, Carlos Guilherme Octavianno do. Experiência e semântica entre os Tremembé do Ceará. In: PACHECO DE OlIVEIRA, João (org.). $A$ viagem da volta: etnicidade, política e reelaboração cultural no Nordeste indígena. Rio de Janeiro, Contra Capa Livraria/LACED, 2004, pp.281-341.

WAFER, Jim. The Taste of Blood: Spirit Possession in Brazilian Candomblé. Filadélfia, University of Pennsylvania Press, 1991.

WEBER, Max. Relações comunitárias étnicas. In: Economia e Sociedade: fundamentos da sociologia compreensiva. Brasília, Editora da UnB, 1991 [v. 1], pp.267-277.

Welzer-LANG, Daniel. A construção do masculino: dominação das mulheres e homofobia. Revista Estudos Feministas, ano 9, 2001, pp.460-481. 
WiLliams, Brackette F. A Class Act: Anthropology and the Race to Nation Across Ethnic Terrain. Annual Review of Anthropology (18), 1989, pp.401-444.

Wolf, Eric. Inventando a Sociedade. In: FELDMAN-BIANCO, Bela; RIBEIRO, Gustavo Lins (orgs.). Antropologia e poder: contribuiçóes de Eric R. Wolf. Brasília, Editora Universidade de Brasília; São Paulo, Imprensa Oficial do Estado de São Paulo/Editora Unicamp, 2003. pp.307-324. 